\title{
Robert Coover's Dirty Stories: Allegories of Reading in "Seven Exemplary Fictions" Louis Mackey
}

\author{
Nothing is gained by continuing to idealize \\ reading, as though reading were not an art of de- \\ fensive warfare. \\ - Harold Bloom \\ Allegorical narratives tell the story of the failure \\ to read. ...
}

- Paul de Man

I HAVE CALLED THEM DIRTY STORIEs. And so they are, not by reason of filthy matter, but essentially. Whatever their theme, the stories dirty themselves. Think of them as self-polluting narratives.

The author's intentions may or may not be honorable: in the "Dedicatoria y Prólogo"1 to "Seven Exemplary Fictions," Coover associates his art with Cervantes' and casts himself as Don Quixote. Tilting his pen at the windmills of myth, he redeems a tradition by deconstructing its forms. But in the "Prologue of Sorts" that is our "Door" (13) into the book as a whole, we are shown a different picture: the writer as Big Bad Wolf lusting unnaturally for the pubescent beauties of fairy tale.

Consider the title. Pricksongs and Descants has a perfectly respectable meaning. A pricksong is a song performed from "pricked"-i.e., written-notes. A descant is a secondary melody counterpointing a primary melody or "burden." Coover's fictions draw their matter from folklore, the Bible, popular culture, and quotidian cliché. His "magic poker" (20) commits these raw materials to writing and converts them into art. Transformed in the transcription, they become descants: counternotations to stories whose burden is old and well-known. Pricksongs and Descants reduces a tradition to an institution and provides it with a bit of dissonant counterpoint, so that it may be rendered by note men. You, "lector amantisimo" (79), and - of course-I.

All this a church musician might understand and approve. But Granny takes a darker view. Thinking of the wolf-author and her silly but innocent granddaughter, the "old Beauty" says: 
I know who's got her giddy ear with his old death-cunt-and-prick songs haven't I heard them all my god and smelt his hot breath in the singin? yes I know him can see him now lickin his hairy black chops and composin his polyphonies outa dread and appetite whisperin his eclogues sprung from disaster croonin his sacral entertainments yes I know him well. ... (16)

Where my reading identifies a high-minded narrative purpose, Granny finds a dirty pun. "Death-cunt-and-prick songs" indeed. To her mind, made wise by experience of the "Beast," the writer is not redeeming a tradition. He's corrupting the young. Composing polyphonies out of dread and appetite (he's still a musician), whispering eclogues sprung from disaster (and a kind of poet), crooning sacral entertainments (is that "sacred" or "sacroiliac"?), the writer turns foolish virgins (you, lector amantísimo, and I?) into withered old hags full of bittersweet memories. ${ }^{2}$

Introducing his own "exemplary" narratives, Robert Coover appeals to don Miguel de Cervantes Saavedra:

The novelist uses familiar mythic or historical forms to combat the content of those forms and to conduct the reader (lector amantísimo!) to the real, away from mystification to clarification, away from magic to maturity, away from mystery to revelation. And it is above all to the need for new modes of perception and fictional forms able to encompass them that I, barber's basin on my head, address these stories. (79)

In the same paragraph, and in Cervantes' words, the author hints at a "hidden mystery" contained in these stories, by which they are lifted above their vulgar occasions. He could hardly assure us, as Cervantes does,

that the amorous episodes you will find in some of them are so respectable and restrained, so within the bounds of reason and conformable to Christian conduct, that no one who reads them, either carefully or carelessly, can possibly be moved to evil thoughts. ${ }^{3}$

Neither writers nor readers are capable - shall I say "any longer"? - of such a pure regard. Without irony-and despite the fact that he has twice as many hands as his "Maestro" - he might "venture to say": 
if I believed that the reading of these [fictions] would in any way arouse an evil thought or desire, I would sooner cut off the hand that wrote them than see them published. ${ }^{4}$

And he does, appropriating the Master's prologue, promise that "there is not one of [these stories] that does not afford a useful example."5

Pricksongs and Descants, morally and musically expounded, agrees with the figure of the writer as Don Quixote, decreating the narrative past and announcing the future of fiction. But "death-cunt-and-prick songs" exposes him as a dirty young man who feeds on the tradition he has ruined. The prologue within the book (by the author) reaffirms (on behalf of the author) a claim that has already been discredited (by one of his characters) in the prologue to the book. Brandishing a two-edged title and prefaces that clash, this book proclaims itself unreadable from the beginning.

The readable text began with Cervantes. Cervantes' novelas are exemplary because they "tell good stories and they tell them well" (77). Cervantes opens a way for the writer into the modern age. Deconstructing and displacing romance, his stories demonstrate, by exemplifying it, the possibility of the novel. Of what do Coover's seven fictions, whose very title echoes the Master's, serve as useful examples? What story does he tell?

As the accompanying table indicates, each of the "Seven Exemplary Fictions" incorporates a metaphor of the text and a metaphor of the reader. The stories themselves enact metaphors of reading and must therefore be taken, in the second degree, as allegories that narrate the impossibility of reading. In each of them save (possibly) one the reader is defeated by his text. In the post-modern age, when naturalism seems to have exhausted its powers, just as romance had become effete in Cervantes' day, Coover's exercises, relentlessly troping their own unreadability as conventional fictions, deconstruct low-mimetic narration and displace it in the direction of the illegible text. So doing, they open the way for "new modes of perception and fictional forms able to encompass them" (79). ${ }^{6}$

The way is strewn with difficulties and mined with occasions of disaster. The failure to read, which these stories both narrate and exemplify, is bound to contaminate-in the third degree-my own (or anyone's) reading. If in reading them anyway I seem to court catastrophe, the ensuing debacle will demonstrate better than any success the (inevitably questionable) legitimacy of my approach. Of the seven I select four, supposing 
them so exemplary of the rest that repeated deployment of the same strategies of reading would yield the same results.

\begin{tabular}{|c|c|c|}
\hline Story & Text & Reader \\
\hline 1. Panel Game & $\begin{array}{l}\text { The game: enigmatic and } \\
\text { perverse }\end{array}$ & $\begin{array}{l}\text { You (Bad Sport, Unwilling } \\
\text { Participant): hanged. }\end{array}$ \\
\hline 2. The Marker & $\begin{array}{l}\text { Jason's wife: dead, maybe } \\
\text { murdered. }\end{array}$ & Jason: emasculated. \\
\hline 3. The Brother & $\begin{array}{l}\text { The Ark: silent and } \\
\text { mysterious. }\end{array}$ & $\begin{array}{l}\text { The narrator: marked for } \\
\text { death. }\end{array}$ \\
\hline 4. In a Train Station & $\begin{array}{l}\text { The story itself: a script } \\
\text { enacted by the characters: } \\
\text { a repetition compulsion. }\end{array}$ & $\begin{array}{l}\text { Alfred: condemned to } \\
\text { endless repetition of } \\
\text { the text }\end{array}$ \\
\hline 5. Klee Dead & $\begin{array}{l}\text { The scrap of paper: the } \\
\text { story itself: illegible, } \\
\text { maybe blank, maybe a } \\
\text { forgery, maybe a handbill. }\end{array}$ & $\begin{array}{l}\text { The person addressed by } \\
\text { the story: you: } \\
\text { cheated and fobbed off } \\
\text { with circus tickets. }\end{array}$ \\
\hline 6. J's Marriage & $\begin{array}{l}\text { J's wife: an impenetrable } \\
\text { Virgin. }\end{array}$ & $\mathrm{J}$ : unmanned and dead. \\
\hline 7. The Wayfarer & $\begin{array}{l}\text { The wayfarer and his } \\
\text { speech: silent or } \\
\text { incoherent. }\end{array}$ & $\begin{array}{l}\text { The police officer: kills } \\
\text { the text in order to } \\
\text { produce his own report. }\end{array}$ \\
\hline
\end{tabular}

1

"Panel Game" is just what it says it is: a TV game show. The cast includes, besides Moderator and Audience, the panel: Aged Clown, Lovely Lady, Mr. America (later Mr. Amentia), and Unwilling Participant, alias Bad Sport, aka ... You. You, the reader, are written into the story and required to answer "THE BIG QUESTION!" (80). The question is never asked. You have to figure out what it is. Question and answer alike wait upon the reader, who, enlisted as an Unwilling Participant in the fiction, is 
expected to guess the name and nature of the fiction. Bad Sport, charged to identify and interpret the narrative in which his life is trapped, resigns himself "to pass the test in peace" (80). Before Moderator formally declares the show begun, Sport scrambles desperately to interpret the hints broadly (and often lewdly) provided by the other panelists. His hermeneutic, which proceeds through a chain of metonymies, puns, rhymes, alliterations, and sexual allusions, is vaguely literary and (though frequently distracted) pointed in the general direction of Shakespeare $(80,81,82$, $83-4,84-5)$. As he frantically tries to follow the clues and find the meaning, he is constantly, tauntingly observed by the Eye of the World: sometimes the television camera and sometimes Lovely Lady's navel.

"And the Bad Sport, you ask, who is he? fool! thou art!" (80). When, well into the proceedings, You speak for the first time-to protest that You don't know how to play the game-You are answered with hostile silence or cruel mockery. Eventually You stumble on the answer, but You don't understand it.

The dog rose and - what? Rose and scrupled? Rose: rows: stichs: stickleback. Going in circles. "Depends-!" gasps America. Can't last long now. Own cells against him. Flesh dogbane pink. "Depends-!"

Depends: hangs. But what hangs or hangs on what? (84)

You do know that "it's your mind they're after. Humor, passion, sobriety, and truth. On you, then, it depends, they depend, they all depend. They all hang. It may be so" (84). With everyone and everything "depending" on You - "what does it mean? what does it mean?"(84)-You try to start a game of Twenty Questions: "II think - . . - That, if the subject is animal-"' (85). But Mr. America announces that it's Too Late, breaks wind, and dies. Dead (85).

That should have told You:

"Come, come, sir!" cries the Moderator, much amused, but rising now and pressing forward. "You must have contrived some concrete conjunctions from the incontrovertible commentary qua commentary just so conspicuously constituted!" Deafening applause.

Dig in! Tie it up! The truth is: "The truth is-" 
"The truth is," shouts the Moderator, jabbing at him with an angry finger, "you have lost!"

"But I haven't even -!"

"Why are you here," the Moderator explodes, losing all patience, "if not to endeavor to disentangle this entanglement?" (85)

You have failed to tell the truth, and You must therefore "PAY THE CONSEQUENCES!" "But the truth is -," You object. "The truth is," says the Clown (86), and goes into a dirty song-and-dance with Lovely Lady, at the end of which the Lady obscenely fakes death. Echoing once more the old refrain, Moderator gives it all away. "The truth is" that

". . . the frame is the same

In fame or in shame

And the name of the game-

-is La Mort!" (87)

A Noose descends.

The name of the game-and the meaning of the life embedded in the game-is: Death. But You, still hung on Shakespearian titles, got it all wrong.

"I thought - " But the Audience drowns you out. Well, they are happy, think about that. The noose is fitted.

"You thought - ?" asks the Moderator and the crowd subsides.

"I thought it was all for fun."

"That is to say," smiles the Moderator wearily, "much ado about nothing."

"That's it! that's it! Yes! that's what I was trying to-!"

The Moderator shakes his head. ... "Sorry." (87)

Aged Clown makes a joke, Audience laughs, Lovely Lady whispers sweet nothings in your ear and gooses you good-bye. "Off you go!" As you dangle, you get - in a way - the answer to the BIG QUESTION: "The dog rose and there depended." But the answer to the question is the end of the game. "So long, Sport" (88). 
Your ordinary television game show (the "real" thing) is generically senseless and more often than not-with its accoutrements of phony camaraderie, gross humor, and snickering sexuality-downright emetic. But even that makes more sense than this "Panel Game." There at least you have determinate questions with straightforward answers. Whereas here . . . where? Coover's game show is a metaphorical text. A text both underdetermined and overdetermined, as obviously meaningful as it is hopelessly without meaning. Unwilling Participant-Bad Sport and eventually bad loser-figures the reader to whom is assigned the impossible task of interpreting the uninterpretable. But of course Sport is also You: at once the reader in the text and the reader of the text. Like an oldtime Calvinist scrounging in his diaries among the random leavings of his life, looking for signs of election, You (in the text) anxiously try to guess the question and the answer while you, with text in hand, try to dope out its meaning. The hermeneutic of life. For the panel game, a metaphor of the text, is transumptively a metaphor of life. Unwilling Participant is "dragged protesting" (79) into the game just as you (with text in hand) are inscribed, without a by-your-leave, in your own life. In both cases (oldtime Calvinism again) the outcome is assured in advance. The game is an allegory of reading is an allegory of life. The question is: what does it mean? And the answer is: nothing. Yours.

"The Marker." Jason and his wife discovered alone in their bedroom. (But there are five policemen outside the door.) Of the wife we are told that she is nude, that she is lovely and affectionate, and that she "has a direct and charming manner of speaking, if we were to hear her speak." We don't. Always at ease, neither pretentious nor shy, she moves about the room, and "whatever meaning there might be in her motion exists within the motion itself and not in her deliberations" (88). An autotelic text, not to be interpreted but loved. Jason, deeply in love with his wife, sits in an armchair reading a book and watching her. As soon as she gets into bed, he puts a marker in his book, undresses, and turns out the light.

His wife's image fades from his mind and is replaced by an image of Beauty "indistinct and untextured" (89). Ever the reader, and now completely in the dark, Jason undertakes a project of interpretation. Groping more or less methodically about the room, he tries in vain to find the bed 
where Beauty and Love await him. The failure of the quest extinguishes his libido. But his wife laughs gently and, turning, he finds the bed where he wasn't looking for it . . right behind him. At the sound of her laugh and the touch of her cool thighs Jason recovers his appetite.

In fact, the experience, the anxiety of it and its riddles, seems to have created a new urgency, an almost brutal wish to swallow, for a moment, reason and its inadequacies, and to let passion, noble or not, have its hungry way. He is surprised to find her dry, but the entry itself is relaxed and gives way to his determined penetration. (90)

Is this really his wife? But who else could it be? As he leans to kiss her, he notices a bad smell.

Suddenly the lights go on and the police enter. (They've been waiting for this moment ever since the beginning of the story.) Looking beneath him, Jason finds his wife three weeks dead and decaying. And himself captivus. Converting reality ("her nude body crackling the freshness of the laundered sheets") into meaning ("an abstract Beauty that contains somehow his wife's ravaging smile and musical eyes") (89), and presuming to take it by force, Jason's hermeneutic is captivated by its own fixation. Which is death: interpretation kills, and once you're into it you're stuck with it.

As the policemen wrench Jason away from his wife's corpse, it clings like a sheet of paper. They carry him to the table "where his book still lies with its marker in it," and the officer, drawing out his genitals-his organs of penetration and his means of interpretation - on the tabletop, pounds them to a pulp (another paper word) with the butt of his gun (91). Before he leaves, the police officer picks up Jason's book, now stained with his own blood, and flips through it. The marker falls to the floor. Jason cries out for his marker, but the officer, replacing the book, "does not hear him, nor does he want to" (92).

Jason is both literally and figuratively a reader. The marker in the bloody book tropes the penis in the dead wife. In the agony of his emasculation, his sole concern is that he has lost his place. All his places - in his text and (equivalently) in his wife-are lost for good. But the violence he suffers is prepared by the violence he offers. When his wife beckons him to the act of love he darkens the room, exchanges her image for an idea, and in the 
obscurity of that abstraction seeks the object of his desire. When he tries to rekindle the lamp it is too late and his desire has gone limp. His wife's motion has a meaning of its own independent of deliberation: Jason looks for meaning through deliberation. Small wonder that when he does find her he finds her desiccated. He has reduced her to a sheet of paper, and he himself-his hermeneutic vigor-is finally reduced to the stuff of paper.

Jason's text is dead, and he (at least) an accomplice in her death. You can almost understand the vehemence of the police officer's revulsion. For although he observes, with "a flicker of compassion" (91) and scarcely more than a flicker of relevance, that neither tradition nor innovation is to be preferred at the expense of the other, since they are mutually originary, nevertheless "some things still make me puke!" (91). Reading is a necrophiliac violence that brings the living spirit to the dead letter in order to penetrate it. Masquerading as an act of love, it inspires the counter-violence by which it is wrenched away from its desire and bereft of its power. Interpretation interruptus. In all of Coover's fictions the act and the art of interpretation are lethal. In "Panel Game" the reader is finally snuffed by the text that mocks his efforts to comprehend it. In this (perhaps) most shocking of the lot he is a murderous exegete who disseminates death and begs his own castration.

3

At 9:27 Alfred buys a ticket and sits down to wait for the 10:18 Express that will take him home to Winchester. Banal conversation between Alfred and the Stationmaster. Enter the stranger, drunk, raving, begging for help. Alfred draws his jackknife, approaches the intruder, weakens, and drops the knife. The Stationmaster picks up the knife, decapitates the stranger, disposes of the remains, and (as the 10:18 pulls out of the station), resets the clock at 9:26. Alfred approaches the ticket window. . .

"In a Train Station" is an infinite narrative loop, a scenario that is going to be played again and again in a never-ending cycle. "But to return ..." (99). Apparently the cause of this eternal recurrence of the same is Alfred's failure to kill the stranger. Were he to seize the moment (it's his cue) and behead the intruder himself, that (it is ambiguously implied) is the one decisive act that might end the cycle and allow him to go home. Assuming, of course, that all this is real (99). But the assumption may not be warranted. It is clear that Alfred and the Stationmaster and the boozy prophet are acting out a familiar script. The clichés they utter are lines in an oft- 
rehearsed performance by which Alfred is frightened (101) and anguished (103), from which he wants to be released, and in which more than once (e.g., 100) he needs to be prompted. '“How's the tomaters doin' this year?"' the Stationmaster asks.

“Aw, well as kin be expected. Need a-look!" Alfred spins suddenly around to confront the Stationmaster, his pale blue eyes damp as though with tears. "Don't ye think maybe this time I could - ?"

"Need a little ...," intones the Stationmaster softly, firmly.

Alfred sighs, turns back toward the gate, works his jaws over the chicken. "Need a little rain," he says glumly. (101)

Don't you think maybe this time I could . . . what? Do the killing myself? Just forget the whole thing, go home, and escape once for all this grisly round? No way. The Stationmaster's reply condemns Alfred, gently but firmly, to the ceaseless repetition of his role.

As the intruder staggers into the station, he addresses Alfred, " 'Our fazher . . . whish art 'n heaven . . . is eating hish own goddamn chil'ren!" Retching and wretched, he adds, “'So help me!'”(102). Alfred fails, the Stationmaster administers the coup de grace while Alfred weeps, and we take it again from the top. The Stationmaster-author, director, prompter, and chief actor in this catastrophe-repeatedly destroys his own children. $\mathrm{He}$ who lacks the courage to play his part - to assume the burden and the responsibility of death - never goes home. Alfred's failure is a failure of interpretation. Though he has the means (the jackknife), he cannot summon the courage to enact the violent hermeneutic demanded by his role. By responding with the violence of murder (a reading that is clearly required of him) to the violent textuality in which he is inscribed, he might (perhaps) break the chain of repetitions and escape, hors texte, to . . Winchester.

Where? Alfred wants to go home. But there's no way he can get there. Before he can catch the 10:18 to Winchester, he is obliged to play out this always already repeated scenario with the Stationmaster and the drunk. Though his desire impels him beyond his role, Alfred is again and again recalled to his dreary destiny: reminded to speak the part set down for him $(100,101)$, reprimanded when he departs from the prescribed stage business (102), goaded to get on with it and reproved when he fails (103). There is nothing outside the text. Winchester, the 10:18, and the rest exist 
only within the script and its performance. There is no "home" to which Alfred can go, no transcendant "meaning" at which he as reader might arrive and in which he might repose. For which reason no doubt the story begins by reminding us that the reality of the scene with all its props and personae is a doubtful assumption at best (99).

Reluctant to play his part and knowing it all too well, Alfred is terrified by the sight of his own jackknife. The tall stranger enters and begins a speech he cannot continue: “'Belovéd! . . . The su'jeck f'my dishcoursh is. . . . The su'jeck . . . the su'ject . . aw, fuck it!' " (101-102). From its opening words ("Belovéd. . .") and from its subsequent parody of the Our Father (102), it is evident the discourse is meant to be a sermon. It ends with a demotic Amen that is also a prayer for death: " 'So help me!" "(102). Alfred knows what he's supposed to do and draws the terrible knife. But he cannot kill, only weep, and the Stationmaster (the only true interpreter) has to finish the job. Alfred misses his train and has to try again. He will never succeed. The preacher's tongue-tied sermon demands, like any sermon, an interpretation in action. Failure to interpret decisively entails perpetual iteration of the demand.

Not that success is any improvement. The Stationmaster (a strong misreader?) does what is required of him, but he too gets another turn on the wheel. Whether we do or whether we don't, we are condemned to do it again. The double violence implicit in "Panel Game" and "The Marker" is here made painfully explicit and its potential even more painfully enacted. There is the violence of the text - the intruder's speech and behavior-and the violence of the reading it asks-murder. If we do not respond with violence to the violence of the text - and even if we do - we are subjected to the ultimate violence (cf. Prometheus, Ixion, Sisyphus, inter alios) of an endless repetition compulsion.

Violence figures once again in the seventh and last of Coover's fictions. But in a way that distinguishes it (perhaps) from all the rest.

\section{4}

"The Wayfarer" reports a police action. A police officer discovers an old man seated beside the highway and interrogates him. Provoked by the wayfarer's unresponsiveness, the officer tortures him, kills him, and prepares to make his report. Which report (a report of which?) we have, presumably, read. 
The figure is plain. An agent of the law encounters inscrutable mystery situated, "on an old milestone" (120), outside the stream of life. The law is determined that everything shall be brought to light and brought to order. ${ }^{7}$ Extending its long arm, it requires of the mystery a full explanation. Interpreting silence as "violation," the law invokes its "unlimited powers" (121) and wastes the mystery.

Throughout the interrogation and the torture, the fortunes of the law are noted and remarked by the travellers who pass by on the road. They commiserate as he approaches his painful duty (120), they reprove him when he seems indecisive, deride his fatuous commands ("I ordered the blood to flow from his . . . nose") (122), and commend him when he kills (123). The officer cannot decide whether the old man's silence expresses fear - "generally a safe" and (for the law) a comfortable "assumption"-or "contempt! The thought, unwonted, jolted me" (121). In either case, the mystery is uncommunicating and uncooperative-he will not even focus his eyes - and cannot be tolerated.

Once the execution is accomplished, the officer is momentarily haunted by the wayfarer's image.

I supposed that this was due to my having stooped down to his level: my motives had been commendable, of course, but the consequences of such a gesture, if practiced habitually, could well prove disastrous. (124)

But he is quickly solaced by the smooth unruffled movement on the road.

Uniformly it flowed, quietly, possessed of its own unbroken grace and precision. There was a variety in detail, but the stream itself was one. One. The thought warmed me. . . . At last, I sat up, started the motor, and entered the flow itself. I felt calm and happy. A participant. I enjoy my work. (124)

It is not quite true that the mystery will not declare itself. After he is shot, but before he dies, the old man opens up:

Suddenly, his eyes fixed on mine. His lips worked, his teeth chewed his beard, I wished he would end it quickly. I even considered firing a 
second shot through his head. And then he spoke. He spoke rapidly, desperately, with neither punctuation nor sentence structure. Just a ceaseless eruption of obtuse language. He spoke of constellations, bone structures, mythologies, and love. He spoke of belief and lymph nodes, of excavations, categories, and prophecies. Faster and faster he spoke. His eyes gleamed. Harmonics! Foliations! Etymology! Impulses! Suffering! His voice rose to a shriek. Immateriality patricide ideations heat-stroke virtue predication-I grew annoyed and shot him in the head. At last, with this, he fell. (124)

The moment of revelation arrives and is refused. Desperate, obtuse, without stops and without syntax, incoherent raving or apocalyptic ecstasy: the prophet speaks and the rifle interprets.

From the first it is assumed, by the minion who executes justice and prepares this report, that the old man will either speak or die. As it turns out, both. Apparently his marginality is enough to activate the rough hermeneutic of the law. The officer prepares to perform his function by extracting his memo-book from his pocket and tapping it with his pencil. When he finds his book empty, he is temporarily unsettled.

I studied my memo-book. It was blank! my God! it was blank! Urgently, I wrote something in it. There! Not so bad now. (121)

Filling that book is the matter of first importance. "Duty, a proper sense of it, is our best teacher: my catechism was coming back to me" (121). The old man's silence is recorded: the officer writes the word aphonia in his book and then erases it. Everything - the nothing that is not there and the nothing that is - must be written. Even the torture and execution of the wayfarer seem to have but one purpose: to fill the memo-book. When his victim finally falls, the officer calls in details of the incident, jots down the vital statistics, anticipates the preparation of his "full report" (124), returns the memo-book to his breast pocket, and rejoins the stream of traffic.

Oddly, though his silence is named and notated, the old man's speech is not reported save in the most indirect ("he spoke of ...") kind of indirect discourse. Itself a violent outburst, its own violence is met by the counterviolence of the death shot. The wayfarer's glossolalia, with its suggestion of mantic authority, is interpreted by the sterner authority of the law: its 
possession of the instruments of death and the solid backing of the social order. Not to mention its supervision of the public record. In Coover's agent of the law we meet at last - and in the first person-a competent reader qualified to explicate the most unforthcoming text, resolve the most chaotically overdetermined discourse, and produce his own definitive report. The only reader in the lot who is not defeated by his task. Small wonder he enjoys his work.

The rest of the seven exemplary fictions exhibit the same pattern. In each of them a metaphor of the text, a metaphor of the reader, and a metaphor of reading conspire to provoke a supervenient allegory of unreadability. In "The Brother," a farmer (figure of the reader) is persuaded against his better judgment and the advice of his pregnant wife to help his crazy brother construct a text - a huge boat - the point of which he cannot for the life of him understand. When the rains come, he misses the boat, loses wife and child, and knows himself marked for death. In "Klee Dead," an unreliable narrator tells the reader (you) a story that manages almost successfully to evade the issue: the death of Wilbur Klee, its motive and its meaning. ${ }^{8}$ At the scene of his demise, you find a scrap of paper that may contain the clue to the mystery, but it is completely illegible, maybe blank, and possibly only a handbill. In lieu of explanation you are offered a pair of tickets to the circus. "J's Marriage" is the familiar tale of a man whose wife-a mysterious virgin whom he cannot penetrate - conceives and gives birth without sex. An uncomprehending reader, $J$ perceives but does not fathom the annunciation and the birth and finally, robbed of his masculine office, dies drunk and consumptive with his face in a glass of red wine. In every case, what is narrated is the failure, by an incompetent or disabled or encumbered reader, to interpret a text that is perversely, obtusely, or mysteriously unreadable.

If the variety of these occasions suggests that life itself is the text, then the monotony in the upshot even more forcefully recommends the conclusion that death, literal or figurative, is its meaning. But death - termination without completion-means nothing. No meaning at all. Thus the text of life defeats every hermeneutic and destroys all its readers. But I need not go out on that limb. Closer to the bole: in each of Coover's stories, a reader confronts a text and and adopts a set of interpretive strategies. In every case (save one?) he loses. He is denied the intelligibility 
he seeks, fobbed off with cheap entertainments, condemned to repeat the text forever without understanding it, emasculated, or killed. Coover's readers are weak misreaders, and they all suffer for it. Only a strong misreader would look at the Ark and imagine the deluge, and perhaps not even the strongest would have concluded the Incarnation from his wife's frigidity. John Barth has said that God wasn't too bad a novelist, except that he was a Realist. ${ }^{9}$ Barth was thinking of the Book of Nature, but has the craziest post-modern fabulator produced anything wilder than the Bible? A book that still defeats its readers.

There is that one (apparent) exception. The strong reader in "The Wayfarer" is no loser. Empowered by the law and supported by his community, Coover's officer obliterates the text that challenges him and writes his own. The wayfarer's unsanctioned existence and his disorderly effusions are replaced jot and tittle by the authoritative text now on file at police headquarters. It's a question of means. Jason's penis/marker, Alfred's jackknife, and Your fumbling philology (Bad Sport) are phalluses that falter and fail. The police officer's pencil/rifle resolutely does its lethal and life-giving work. Their means of interpretation are expunged or expropriated. His accomplishes a full report.

In his Prólogo, Coover addresses don Miguel:

For your stories also exemplified the dual nature of all good narrative art: they struggled against the unconscious mythic residue in human life and sought to synthesize the unsynthesizable, sallied forth against adolescent thought-modes and exhausted art forms, and returned home with new complexities. In fact, your creation of a synthesis between poetic analogy and literal history (not to mention reality and illusion, sanity and madness, the erotic and the ludicrous, the visionary and the scatological) gave birth to the Novel - perhaps above all else your works were exemplars of a revolution in narrative fiction, a revolution which governs us-not unlike the way you found yourself abused by the conventions of the Romance - to this very day. (77)

Cervantes brought off a revolution in narrative fiction which has governed writers-e.g., Robert Coover-"to this very day." And now abuses them. Like Cervantes (and perhaps like Little Red Riding Hood in "The 
Door" [17-19]), the modern writer is a liminal figure. But while Cervantes stepped from a closed world into an open universe, we feel our world closing in on us again.

Like you, we, too, seem to be standing at the end of one age and on the threshold of another. We, too, have been brought into a blind alley by the critics and analysts; we, too, suffer from a "literature of exhaustion," though ironically our nonheroes are no longer tireless and tiresome Amadises, but hopelessly defeated and bed-ridden Quixotes. We seem to have moved from an open-ended, anthropocentric, humanistic, naturalistic, even - to the extent that man may be thought of as making his own universe-optimistic starting point, to one that is closed, cosmic, eternal, supernatural (in its soberest sense), and pessimistic. (78)

Of all the characteristics here enumerated, only the last - "pessimistic"sounds unmedieval. The modern world is a recapitulation, sadder if not wiser, of the Middle Ages. Once again the writer sees his world as the microcosm of a larger "Design" and probes "beyond the phenomenological, beyond appearances, beyond randomly perceived events, beyond mere history." Like the Knight of the Mournful Countenance, he sallies forth to challenge "the assumptions of a dying age" (78). Barber's basin on his head, the modern writer tilts at illusions in order to disclose reality and conduct his reader to clarity, maturity, and revelation. He engages the preconceptions of the age quixotically, by taking them seriously, and by opposing them he lays bare the truth they dissimulate.

Coover's art is an art of disenchantment. In this respect he is Cervantes redivivus. Like the Master's, his stories are his experiments in writing (76-77). But he is doing Cervantes in reverse. Whereas Cervantes' novelas are exemplary because "they tell good stories and they tell them well" (77), Coover's fictions illustrate the impossibility of reading and the difficulty of writing. Witness "The Door." Here in the Prologue ("of sorts") to the book as a whole, where you might expect the writer in propria persona to give you a concise statement of his purpose, his program, and his achievement, what you get is a clutter of narrators, fairy-tale identities hopelessly confused and conflated, who cannot seem to agree on just what stories to tell-pricksongs and descants or death-cunt-and-prick 
songs - and what those stories might communicate-a new knowledge of reality or a new brand of illusion. We, who have read (!) the seven exemplary fictions, know what kind of stories they are-both of the aboveand what they mean - nothing you can lay your hands on.

The writer as Big Bad Wolf seduces and devours the wisdom of his tradition, and the writer as Don Quixote hacks away at mythic windmills. Both of him perpetrate violent acts: the violent imposition of order on the "flux and tedium" (16) of innocent experience or the violent deranging of an experience already compromised by the violence of prior order. His weapon-his "thick quick cock" (17) and his potent lance-is language. To read Coover's seven deadly fictions is to oppose the counter-violence of interpretation to the originary violence of writing and to commit thereby yet another offense of language.

To the violence which these texts inflict on the conventions of verisimilitude I respond with the counter-violence of allegorical reading. I call the police on these offenders. Or take the law into my own hands. The outcome of this encounter is not the restoration of law and order but the purification of conflict: the act of communication is always thwarted (love is entrapped by death), and the recovery of meaning is always deferred (we never catch the train that will take us home). The recognition of these inevitabilities is itself a liberation of writing and of reading for the fuller exercise of their actual and always contested powers.

Provided we are not then captivated by the illusion of release. The last desire from which we must liberate ourselves is the desire for liberation. Seen in this light, "The Wayfarer" - that apparent exception - is misleading. Coover's efficient peace officer wraps up the case and returns to headquarters happy in his work. But his success is a sham and a shambles. His reading, strong as it is, does not issue a full and final report. It only prolongs the history of violence. And the peace he leaves us with is no more than a deceptive euphoria induced by his own and (if it fools us) our submersion in the stream of life. His reading goes through, but only because it is wholly inscribed within the order enforced by his community. By every community, whether it be the community of culture or the community of interpretation. It is not hard - it may even be mandatory - to imagine that smoothly flowing traffic as the literary-critical establishment.

Calling the police, a summons necessary to complete any act of reading, succeeds in the only way a violent act can succeed. It sets the stage for fur- 
ther violations. No reading is final save by fiat or by consensus, forced terminations that challenge interminable revision. As Bloom has argued, there are no readings pure and simple. There are only misreadings, the strength of which is measured by their power to stimulate more of the same. Every reading is a trope waiting to be sprung.

Granny is right. These are dirty stories. But not because of their obsession with sex and death. What they offend is not our moral sensibilities, but the canons of critical responsibility. Experimental in this sense, they severely try the conventions of imitation and the norms of interpretation. Coover's fictions and the hermeneutic that is up to them enact the rape of representation and the death of the innocent reader.

The narrative technique employed in "Seven Exemplary Fictions" is not without precedent or parable in American literature. Here is our strongest reader affronting the text that finally did him in:
All visible objects, man, are but as pasteboard masks. But in each event -in the living act, the undoubted deed-there, some un- known but still reasoning thing puts forth the mouldings of its fea- tures from behind the unreasoning mask. If man will strike, strike through the mask! How can the prisoner reach outside except by thrusting over the wall? To me, the white whale is that wall, shoved near to me. Sometimes I think there's naught beyond. But 'tis enough. He tasks me; he heaps me; I see in him outrageous strength, with an inscrutable malice sinewing it. That inscrutable thing is chiefly what I hate; and be the white whale agent, or be the white whale principal, I will wreak that hate upon him. Talk not to me of blasphemy, man; l'd strike the sun if it insulted me. For could the sun do that, then could I do the other; since there is ever a sort of fair play herein, jealousy presiding over all creations. But not my master, man, is even that fair play. Who's over me? Truth hath no con- fines. ${ }^{10}$

Starting with his own contemporaries, American writers have doggedly made it their business to rebut Emerson's conviction that brute fact passes without remainder into transcendental truth. ${ }^{11}$ By now it's a tradition: Hawthorne and Melville its patrons, Whitman its reluctant fellow-travel- 
ler, and Pynchon its adept. The burden of the tradition is to insist on the intransigent opacity of fact: fact that will not convert to meaning or that only so converts in a forced exegesis that both distorts the fact and shatters the meaning. It is this harping on the irreducibility of fact that produces the unreadable text. Ontology blocks epistemology.

In Snow White, Donald Barthelme gives us the unreadable text (and a vision of contemporary American life) in the form of a fairy tale reduced to a trash heap. A pile of plastic buffalo hump which cannot be interpreted but only appreciated. Coover does not ask us to cultivate a taste for dreck. His purpose is not to undo but to redo, for the post-modern age, Cervantes' revolution. He characterizes his own narrative tactics - his peculiar way of pricking and descanting the burden of tradition-in these words:

I like to use the original mythical materials and deal with them on their home ground, go right there to where it's happening in the story, and then make certain alterations in it, and let the story happen in a slightly different way. The immediate effect is to undogmatize it so that at least minimally you can think of the story in terms of possibility rather than as something finite and complete. ${ }^{12}$

Under any description, Pricksongs and Descants is an experimental work. This is Coover's experimental method, what he calls in the case of Cervantes his "writing ideas" (76). Typically he begins with a familiar story from the Bible, folklore, children's literature, pop culture, what-haveyou. Then he opens it up, tells it from a novel point of view, introduces new and often preposterous givens, allows the narrative to take a different and usually startling tack at crucial junctures, or just lets the story go off simultaneously in all the directions it might take. The first effect of these techniques is to block all the standard reader responses and to encourage "communication across reality links, not across conventional links."13

It is the writer as Big Bad Wolf who makes possible the writer as Don Quixote. By his perverse consumption of traditional materials, Coover loosens the strangle-hold which these materials in their conventional forms have on the reader. Disengaging matter and form, he enables us to perceive both afresh - if not originally, then at least more primitively than before, and if not immediately, then at least without the usual narcotic mediations. Recast in Coover's way, the old story becomes not an occa- 
sion for knee-jerk reaction but a locus of undecidable possibilities.

The reader in Coover's fiction, who is always figuratively and sometimes literally identical with the reader of the fiction, invariably tries to subsume the brute and carnal facts that affront him into some superintendent significance. Each of the seven exemplary fictions shows us a reader struggling to contain the data of experience within a system - ideal, mythical, linguistic, narrative, etc. - that will give them meaning. Invariably he tries, and just as invariably he fails. Stones are not sermons, and reality is never a source of messages.

Ontology blocks epistemology. But the distinction is specious. As there are no meanings latent in fact awaiting exegesis, so there are no facts that irresistibly resist explication. Every fact is already a meaning, and a meaning is a fact as hard as any. Beyond the transcendentalist aspiration and the realist demurrer, fact and meaning alike are interchangeable counters in a panel game which generates no final meaning and comes to rest on no fundamental fact. In which (in fact) even the name of the game is up for grabs.

Coover's superficial subject-matter is most often (what else is new?) Love and Death. But the love is commonly drawn toward a sexuality that castrates and kills, and the death whether swift or lingering is usually painful and without point, so that his "deep" subject is violence. Grotesque and excessive, the effect of the violence is to shock us out of interpretation and force us into essays in redemptive hermeneutic. But the facts resent interpretation as surely as the interpretations collapse in the face of the facts that demand them. Both matter and form are unreadable: the matter inexponible in meaning and the form unexhibitable in fact. The meaning of Coover's fictions (their illegibility) doubles their matter (life as it is suffered) without redundancy. Substance and significance coincide without coalescing, and their duplicity reduplicates the double meaning of Coover's title. Pricksongs and descants (unreadable texts) are also deathcunt-and-prick songs (love and death), and this irreducible duality both structures and perpetuates our (necessarily) violent encounter with both. To read them is certainly an experience that exercises - vigorously - all the imagination we have.

\section{Notes}

1. Robert Coover, Pricksongs and Descants (New York: New American Library, 1969), pp. 76-79. All further references to this work will be given parenthetically in the text. 
On Coover's Dedicatoria y Prólogo, cf. Jackson I. Cope, "Robert Coover's Fictions" (The Iowa Review, v. 2, n. 4, 1971), pp. 99-100. Cope's essay, which deals mainly with The Universal Baseball Association, Inc., J. Henry Waugh, Prop., is also, not quite per accidens, an illuminating commentary on the Valeryan epigraph Coover chose for Pricksongs and Descants: "They therefore set me this problem of the equality of appearance and numbers." For Coover's perception of his debt to Cervantes, cf. "Robert Coover: An Interview with Alma Kadragic," Shantih, v. 2, n. 2, 1972, pp. 57-60; Frank Gado, First Person: Conversations on Writers and Writing (Schenectady: Union College Press, 1973), pp. 142-159; Robert Coover, "The Last Quixote," New American Review, 11, 1971, pp. 132-143. My approach to Coover in this essay is anticipated (so far as I know only) by Monique Armand in "Les jeux de l'enonciation dans 'Panel Game," Delta, 8, 1979, pp. 189-203. One salient fact about Coover's fiction which I have ignored and perhaps obscured is that it is funny. In Leo J. Hertzel, "An Interview with Robert Coover," Critique, v. 11, n. 3, p. 28, Coover says: "I tend to think of tragedy as a kind of adolescent response to the universe - the higher truth is a comic response ... there is a kind of humor extremity which is even more mature than the tragic response. . . . Thus some of the great ironic, comic fiction can nevertheless be equal to the same kind of strange emotion you get out of tragedy because your emotions can be mixed." In the novels and in many of the short pieces, though the subject-matter is often grim enough, the overall tone is comic. This is not true of "Seven Exemplary Fictions," for which reason I have been silent about Coover's dark gray humor. But I do not want to give a misleading impression of his work as a whole. He may be a scribe of mournful countenance, but he is never grave.

2. For Coover's interpretation of the title, Pricksongs and Descants, cf. Gado, op. cit., pp. 150-151.

3. Samuel Putnam, trans. and ed., The Portable Cervantes (New York: Penguin Books, 1978), p. 707.

4. Ibid. My brackets.

5. Ibid. My brackets. Cf. Pricksongs and Descants, p. 77. Though Cervantes himself is not explicit about the sense in which his stories are exemplary, Coover provides him with a rationale. $V$. infra.

6. Elsewhere in Pricksongs and Descants, especially in "The Magic Poker" (pp. 20-45), Coover explores the problems and possibilities of writing.

7. On the demands of the law, cf. Jacques Derrida, "La Loi du genre/The Law of Genre," Glyph 7, pp. 176-229.

8. For what it's worth: "Klee Dead" speaks directly to its reader. In "Panel Game" the reader is written into the story as one of its characters. In the remaining five stories the reader, though always presupposed, is neither addressed nor incorporated.

9. Quoted in Robert Scholes, Fabulation and Metafiction (Urbana: University of Illinois Press, 1979), p. 76.

10. Herman Melville, Moby-Dick(New York: W. W. Norton, 1967), p. 144.

11. Cf. David Porter, Emerson and Literary Change (Cambridge: Harvard University Press, 1978), ch. 3. 
12. Kadragic, op. cit., p. 60. Coover's experiments in narration have their example in Cervantes. In the Novelas and in Don Quijote Cervantes tampers more or less irreverently with the conventions of, e.g., romance and the picaresque in order to produce the generically eclectic narrative that eventually becomes the modern novel. It may well be the case that the novel has always been an experimental form, and that the experimentation of postmodern writers, while often different in kind and in degree from past experiments, is as such nothing new.

13. Hertzel, op. cit., p. 27. 